\title{
At-Turats
}

Jurnal Pemikiran Pendidikan Islam

journal homepage: http://jurnaliainpontianak.or.id/index.php/atturats

\section{METODE PENDIDIKAN ANAK PEREMPUAN PERSPEKTIF ISLAM DAN PSIKOLOGIS DALAM Q.S. ALI IMRAN AYAT 35-37}

\author{
Sri Wahyuni Alwi a, M. Husni Arsyad ${ }^{\text {b }}$ \\ ${ }^{a}$ Universitas Islam Negeri Sunan Kalijaga \\ Pascasarjana Psikologi Pendidikan Islam, Yogyakarta, Indonesia \\ ${ }^{b}$ Universitas Islam Negeri Sunan Kalijaga \\ Magister Pendidikan Bahasa Arab, Yogyakarta, Indonesia
}

\begin{abstract}
Abstrak
Penelitian ini bertujuan untuk mengetahui metode-metode pendidikan anak perempuan yang terkandung di dalam Al-Qur'an, khususnya pada kisah Maryam binti Imran dalam Q.S. Ali Imran ayat 35, 36, dan 37 beserta hubungannya dengan hadis-hadis Rasulullah dan kajian psikologis. Penelitian ini merupakan penelitian kualitatif yang bersifat literar (library research) dengan menggunakan pendekatan semiotika. Sumber data penelitian ini diperoleh dari data-data kepustakaan seperti Al-Qur'an, hadis-hadis Rasulullah, buku, kitab tafsir, dan informasi-informasi terkait yang diperoleh dari internet. Analisis semiotik pada Q.S. Ali Imran ayat 35-37 dilakukan dengan menggunakan dua pembacaan, yaitu pembacaan heuristik dan pembacaan hermeneutik. Hasil penelitian menunjukkann bahwa kisah Maryam binti Imran dalam Al-Qur'an ayat 35 mengandung metode pendidikan anak perempuan sejak masa pranatal atau masa dalam kandungan, di bawah pendidikan ayah dan ibunya; ayat 36 menggandung metode pendidikan anak perempuan saat masa postnatal atau masa kelahiran di bawah pendidikan seorang ibu; dan ayat 37 menggandung metode pendidikan anak perempuan dalam pengasuhan sejak bayi, anak-anak, hingga dewasa di bawah pendidikan seorang ayah.
\end{abstract}

Kata kunci: anak perempuan, maryam binti imran, metode, pendidikan, semiotika

\section{PENDAHULUAN}

Dalam dunia pendidikan, kebangsaan, budaya, sosial, agama, maupun hukum, telah banyak terjadi ketidakwajaranketidakwajaran yang akhirnya memakan sejumlah korban. Di dunia pendidikan misalnya, pada tahun 2018 ini di Indonesia terdapat sebanyak 2.227 kasus kekerasan terhadap anak-anak didik, khususnya anak perempuan, yang dilakukan oleh ayah kandungnya sendiri, paman, guru laki-laki, bahkan pacar. Kekerasan tersebut dilakukan dalam bentuk kekerasan fisik, kekerasan seksual (perkosaan, persetubuhan, pencabulan, dan pelecehan seksual), kekerasan psikis, dan kekerasan ekonomi (Komnas Perempuan, 2018).

Secara perbedaan gender, anak perempuan dipandang memiliki kemampuan fisik dan kemampuan matematika yang lebih rendah dibandingkan dengan anak laki-laki (Santrock, 2008). Anak perempuan juga disebutkan memiliki kecerdasan yang lebih rendah dibandingkan anak laki-laki (Nurhayati, 2011). Pada umumnya perempuan dicitrakan sebagai mahluk yang emosional, mudah menyerah (submisif), pasif, subjektif, mudah terpengaruh, dan memiliki dorongan seks yang rendah. Akibat citra fisik yang dimiliki, perempuan dikatakan sebagai mahluk yang tidak sempurna (second class), mahluk yang tidak 
penting (subordinate), sehingga selalu dipinggirkan (marginalization), dieksploitasi, dan diposisikan hanya mengurusi masalah domestik dan rumah tangga, seperti dapur, kasur, dan sumur. Dalam bidang pendidikan, minimnya jumlah perempuan yang ahli di bidang sains, politik, dan ekonomi sehingga perempuan dipandang lemah serta tidak mampu dalam berprestasi (Nurhayati, 2011).

Melihat banyaknya kasus terhadap anak perempuan, serta citra dan kekurangan yang mereka miliki tersebut, maka anak-anak perempuan selayaknya memperoleh pendidikan dan pengasuhan khusus yang berbeda dengan laki-laki sejak berada di dalam rahim ibu hingga mereka dewasa. Setiap orang tua maupun guru sebagai pendidik memiliki tugas penting untuk mendidik setiap anak perempuan dengan metode-metode khusus selama masa perkembangannya, sehingga anak perempuan dapat tumbuh berkembang menjadi mahkluk yang tidak direndahkan atau dipinggirkan dibandingkan dengan anak laki-laki.

Dalam Islam, metode pendidikan secara luas adalah cara yang digunakan dalam upaya mendidik dengan nilai-nilai Islam (Tafsir, 2014). Berbicara tentang pendidikan dalam Islam, maka tidak akan pernah lepas dari Al-Qur'an dan Al-Hadits. Al-Qur'an hadir dengan berbagai macam konsep serta metode dalam mendidik anak bahkan manusia secara umum. Rasulullah, Muhammad shallallahu 'alaihi wasallam sepanjang hidupnya dihabiskan dengan menjadi teladan yang baik dalam hal ibadah, mendidik, muamalah, maupun kepemimpinan. Adapun mendidik yang dimaksud menurut Arifin (Hasan, 1994) adalah membimbing dan mengarahkan pertumbuhan dan perkembangan dari tahap ke tahap kehidupan anak didik sampai mencapai titik kemampuan yang optimal.

Berdasarkan perspektif keislaman dan psikologis, telah banyak penelitianpenelitian sebelumnya yang membahas mengenai metode pendidikan anak. Namun, belum ada satupun yang secara khusus meneliti dan membahas metode pendidikan anak perempuan sejak sebelum lahir hingga pasca lahir, dengan menganalisis kisah Maryam binti Imran yang terdapat di dalam Al-Qur'an. Memang, sangat banyak kisah di dalam Al-Qur'an yang membahas mengenai metode pendidikan anak, namun kebanyakan metode tersebut terkandung dalam kisah para Nabi dan anak-anak laki-lakinya, serta lebih fokus pada pendidikan anak laki-laki (Tafsir, 2014).

Secara khusus, kisah mengenai anak perempuan dari masa pra lahir hingga dewasa hanya terdapat pada kisah Maryam binti Imran, yang merupakan satu-satunya wanita yang Allah menyebutkan namanya beberapa kali dan mengabadikannya di dalam AlQur'an, dengan menjadikan namanya sebagai salah satu nama surat. Dalam Al-Qur'an dikisahkan Maryam binti Imran selama masa hidupnya memperoleh pendidikan yang luar biasa, baik dari kedua orang tuanya terutama ibunya, dari Nabi Zakaria sebagai seorang pengasuh Maryam sekaligus seorang guru baginya, dan pendidikan dari malaikat Jibril yang menjelma menjadi manusia. Pendidikan yang diperoleh Maryam tersebut membuatnya tumbuh menjadi pribadi yang baik secara fisik maupun psikis. Oleh karena itu, menurut peneliti kisah Maryam binti Imran memiliki banyak makna dan pesanpesan yang menarik untuk diungkap mengenai metode pendidikan anak perempuan, yang akan berguna bagi dunia pendidikan, baik di kalangan orang tua, maupun para guru di sekolah.

Melihat pentingnya kisah Maryam binti Imran tersebut, maka peneliti bertujuan untuk mengetahui metode-metode pendidikan anak perempuan yang terkandung di dalam kisah Maryam binti Imran beserta hubungannya dengan hadis-hadis Rasulullah dan kajian psikologis. Peneliti membatasi penelitian ini dengan hanya fokus pada pendidikan Maryam binti Imran yang diperoleh dari kedua orang tuanya serta dari Nabi Zakariya, yang terdapat dalam AlQur'an surat Ali Imran, ayat 35, 36, dan 37.

\section{Metode Penelitian}


Penelitian ini merupakan penelitian kualitatif yang bersifat literar atau kepustakaan (library research). Sumber data penelitian ini diperoleh dari data-data kepustakaan seperti Al-Qur'an, hadis-hadis Rasulullah, buku, kitab tafsir, dan informasiinformasi terkait yang diperoleh dari internet.

Penelitian ini dilakukan dengan menganalisis teks kisah Maryam binti Imran dalam Al-Qur'an surat Ali Imran ayat 35, 36, dan 37 menggunakan pendekatan semiotika, guna menggali metode-metode pendidikan anak perempuan yang terkandung di dalam tanda dan maknanya. Selanjutnya, untuk dapat melengkapi analisis tersebut, peneliti juga menghubungkan hasil analisis dengan beberapa hadis Rasulullah mengenai pendidikan anak perempuan, serta teori-teori dan hasil-hasil penelitian dalam kajian psikologi.

Semiotika secara singkat didefinisikan sebagai ilmu tentang tanda, pertanda, makna dari sistem tanda, serta tentang bagaimana tanda dari jenis karya apapun dalam masyarakat yang mengkomunikasikan makna (Fiske, 2006) Hubungan antara penanda dan petanda AlQur'an ditentukan oleh konvensi-konvensi yang melingkupi teks Al-Qur'an. Konvensi tersebut adalah kode atau tata aturan dalam ruang lingkup linguistik (Imran, 2011). Allah dengan sengaja menjadikan bahasa verbal sebagai sarana komunikasi antara Dia dengan manusia yang telah tertulis rinci dalam AlQur'an, maka dapat dipastikan di dalam bahasa tersebut terdapat berbagai macam tanda yang harus dipahami manusia sebagai penerima pesan. Dalam ranah kajian semiotika terhadap Al-Qur'an, dapat dikatakan bahasa Arab yang merupakan medium sebagai sistem tanda tingkat pertama (Imran, 2011).

Analisis semiotika dalam penelitian ini dilakukan dengan menggunakan dua macam pembacaan, yakni pembacaan heuristik dan pembacaan hermeneutik. Pembacaan heuristik adalah pembacaan berdasarkan konvensi bahasa sebagai sistem semiotik tingkat pertama, dengan cara pembaca maupun peneliti mengartikan makna kata dalam suatu teks termasuk AlQur'an secara bebas (Wicaksono, 2014). Adapun pembacaan hermeneutik adalah sebuah prosedur analisis makna, dengan cara menginterpretasikan teks atau objek penelitian ke dalam pemahaman peneliti atau pembaca, dalam rangka menjadikan makna yang terdapat di dalamnya lebih jelas dan lebih mudah dimengerti (Wicaksono, 2014).

\section{Analisis Semiotika Q.S. Ali Imran Ayat} 35

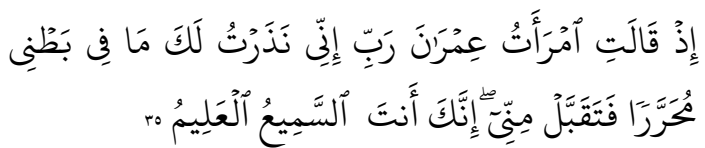

“(Ingatlah), ketika istri 'Imran berkata: 'Ya Tuhanku, sesungguhnya aku menazarkan kepada Engkau anak yang dalam kandunganku menjadi hamba yang saleh dan berkhidmat (di Baitul Maqdis). Karena itu terimalah (nazar) itu daripadaku. Sesungguhnya Engkaulah Yang Maha Mendengar lagi Maha Mengetahui,.”

Kata imraatu 'imra>na (إمْرَاََةُ عِمْرَانَ) pada permulaan ayat ini merupakan tanda sangat penting, yang mengacu pada tokoh sentral pada fragmen ini yaitu istri Imran, Hannah binti Fa'quzl. Penggunaan $t a$ ' maftuhah $(ت)$ pada kata imraatu menandakan bahwa keputusan untuk bernazar kepada Allah itu merupakan keputusan pribadi dari istri Imran saja, bukan merupakan keputusan bersama dengan suaminya, sehingga ia tidak mengatakan nazlarna> (نَ نَذَزْنَسا : kami bernazar). Selain itu, Hannah juga mengatakan taqabbal minni> (terimalah nazar itu daripadaku), bukan mengatakan

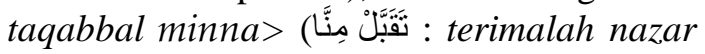
itu daripada kami). Keputusan pribadi dari istri Imran tersebut mempunyai tanda bahwa ketika terjadi nazar, Imran tidak berada di sisi istrinya. Hal itu sebagaimana yang dikatakan oleh (Al-'Arali, 2017) bahwa Imran telah wafat sebelum persalinan istrinya atau sebelum terjadinya nazar.

Istri Imran pada ayat ini bermunajat kepada Allah dengan menggunakan kata nazlara (نَ (نَـنَزَ). Al-Sya'rawi (1991) 
mendefinisikan Nazlar sebagai suatu hal yang diniatkan untuk ketaatan yang dilakukan lebih banyak dari apa yang telah dibebankan dari salah satu jenis ibadah atau ketaatan yang telah Allah perintahkan. Contohnya, jika seseorang telah bernazar bahwa dia akan menambahkan sholat wajibnya dengan sholat sunnah maka ia telah mewajibkan dirinya dengan sesuatu (ibadah) yang lebih banyak daripada yang Allah telah wajibkan.

Kata nazlartu (نَـَنَرْتُ) pada ayat ini menunjukkan istri Imran telah bernazar dan merupakan penanda bahwa ia adalah wanita yang taat dan bertaqwa. Hal tersebut dilakukan tanpa adanya paksaan, ia bernazar dengan perkara tambahan dalam rangka perkhidmatan kepada Baitul Maqdis. Istri Imran bernazar kepada Allah agar janin yang ada dalam perutnya kelak ketika lahir ia menjadi muharrar. Kata muharrar (مُحَرَّرَاً (م) dalam ayat ini adalah istilah yang digunakan oleh Bani Israil dalam menyebut anak-anak kecil yang dikhususkan untuk berkhidmat kepada Baitul Maqdis. Kata muharrar merupakan isim maf'u>l dari fi'il harrara

(حَـ)yang berarti membebaskan (Munawwir, 2001). Adapun makna muharrar adalah bukan kepunyaan seseorang (Al-Sya'rawi, 1991). Kata muharrar memiliki tanda bahwa siapa saja yang menjadi muharrar (anak yang berkhidmat) kepada Baitul Maqdis, maka ia terbebas dari berkhidmat kepada orang tuanya.

Secara keseluruhan, ayat 35 pada surat Ali Imran juga memiliki tanda tersendiri. Dalam ayat tersebut dibahas tentang metode pendidikan seorang ibu dalam masa kehamilannya terhadap janin yang dikandungnya. Perilaku bernazar yang dilakukan Hannah mengandung makna dan pesan bahwa pendidikan keluarga terhadap anak tidak hanya setelah anak tersebut lahir ke alam dunia, melainkan sejak mengetahui keberadaanya di dalam kandungan seorang ibu. Metode pendidikan anak perempuan yang terdapat dalam perilaku Hannah adalah pertama-tama kedua orang tua, baik suami maupun istri agar meniatkan untuk memiliki dan mendidik seorang anak semata-mata karena Allah serta sebagai bentuk ibadah kepada-Nya. Selain niat yang baik, kisah tersebut juga mengajarkan kepada setiap keluarga agar para istri banyak menyematkan harapan mulia teruntuk calon buah hati yang masih ada dalam kandungan seperti harapan mulia istri Imran, serta banyak mendo'akan bagi calon jabang bayi agar kelak menjadi seseorang yang baik dan mulia selama berada dalam kandungan.

Ungkapan yang disebutkan Hannah dalam bernazar berupa "Apa yang ada di dalam perutku" menandakan bahwa Hannah saat mengetahui dirinya hamil hingga menjelang persalinannya, ia sama sekali tidak mengetahui apakah anak yang ada di dalam perutnya berjenis kelamin laki-laki ataukah perempuan. Hannah hanya berharap bayi yang dikandungnya tersebut adalah seorang anak laki-laki tanpa mengetahui kejelasan jenis kelaminnya, sehingga bernazar dengan menggunakan kata muharrar, yang menjurus pada anak laki-laki. Perilaku Hannah tersebut menyiratkan satu metode pendidikan anak, bahwa mengetahui atau tidak jenis kelamin bayi yang sedang dikandung, sebagai orang tua calon buah hati hendaknya selalu dan tetap mendo'akan kebaikan-kebaikan untuknya.

Metode lain yaitu, Hannah juga menyiapkan anaknya untuk berkhidmat kepada Allah. Maksud berkhidmat di sini bukan berarti harus menjadi ulama atau ustadz. Akan tetapi, apapun pekerjaan atau profesi yang digeluti oleh seorang anak nantinya, maka orang tua tidak boleh lupa untuk menanamkan nilai-nilai ketuhanan semenjak dini, bahkan sebelum anak itu dilahirkan. Hal inilah yang dilakukan oleh Imran dan istrinya. Oleh karena itu sudah menjadi tugas para orang tua mempersiapkan anaknya semenjak belum lahir agar kelak menjadi hamba Allah yang senantiasa berkhidmat kepada Allah. Jika anak itu menjadi seorang pengusaha, maka ia bisa berjuang di jalan Allah dengan hartanya. Jika anak itu menjadi seorang ulama atau ustadz, maka ia bisa berjuang di jalan Allah dengan ilmunya. 
Perilaku Hannah yang bernazar dengan meniatkan serta mengharapkan Maryam menjadi anak yang baik sejak berada di dalam kandungannya tersebut berpengaruh hingga Maryam tumbuh dewasa. Hal itu menunjukkan pikiran positif yang ditanamkan seorang ibu ketika sedang mengandung mempengaruhi perkembangan moral seorang anak dalam setiap tahap pertumbuhannya. Berdasarkan niat yang baik itulah Maryam menjadi pribadi yang baik serta taat kepada Allah, hingga dinobatkan menjadi penghuni surga terbaik, yakni pemuka kaum wanita di surga. Dari Aisyah radhiyallahu 'anha, bahwa Rasulullah shallallahu 'alaihi wasallam bersabda:

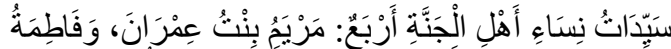

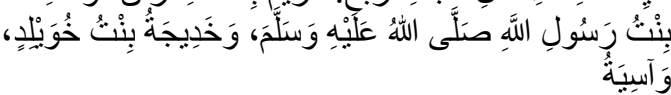

"Pemuka wanita ahli surga ada empat: Maryam binti Imran, Fatimah binti Rasulullah, Khadijah binti Khuwailid, dan Asiyah." (HR. Hakim 4853 dan dinilai adDzahabi: shahih sesuai syarat Muslim dan juga dinilai shahih oleh al-Albani dalam Shahihul Jami' 3678).

Dalam hadis tersebut Rasulullah meletakkan posisi Maryam di paling pertama dalam penyebutan pemuka kaum wanita di surga. Hal itu menunjukkan keutamaan Maryam binti Imran dalam pandangan Rasulullah serta tingginya derajatnya di antara setiap wanita di dunia.

Perilaku bernazar dan berdo'a (dalam ayat tersebut) yang dilakukan istri Imran juga menunjukkan bahwa ia adalah seorang wanita yang taat, patuh, dan bertaqwa kepada Allah subhanahu wata'ala. Hal itu terlihat dari kesabarannya yang luar biasa dalam menanti kehadiran sang buah hati selama bertahun-tahun pernikahannya dengan Imran. Di samping sabar, ia juga selalu berdo'a kepada Allah agar dikaruniai seorang anak. Selain istrinya, Imran juga merupakan seseorang yang sholeh, menjadi pemuka di kalangan Bani Israil, dan masih mempunyai garis keturunan dari Nabi Daud 'alaihissalam (Isma>'il, 1999). Oleh karena keshalihan kedua pasangan suami istri inilah Allah secara langsung memilih keluarganya menjadi keluarga yang paling baik di seluruh alam. Hal itu termaktub dalam firman-Nya yang artinya "Sesungguhnya Allah telah memilih Adam, Nuh, keluarga Ibrahim, dan keluarga Imran melebihi segala ummat" (Q.S. Ali Imran: 33). Selain diakui oleh Allah dan Rasulnya, seluruh kaum Bani Israil saat itu juga memandang Imran dan istrinya sebagai hamba Allah yang tidak pernah berbuat sesuatu yang buruk lagi keji. Penjelasan mengenai hal itu juga tercantum dalam firman-Nya yang artinya "Hai saudara perempuan Harun, ayahmu sekalikali bukanlah seorang yang jahat dan ibumu sekali-kali bukanlah seorang pezina" (Q.S. Maryam: 28).

Lantas, apa pengaruh akhlak dan pribadi shaleh Imran dan Hannah dalam pendidikan Maryam? Hasil penelitian di bidang behavioral-genetika telah menemukan bahwa orang tua memiliki pengaruh terhadap trait anak-anak mereka yang diwariskan secara genetis (Wade \& Tavris, 2007). Plomin \& Cabbe (Wade \& Tavris, 2007) mengemukakan bahwa selain bentuk fisik, sifat psikologis juga tergantung pada berbagai gen, dan satu gen dapat mempengaruhi berbagai macam perilaku. Hal tersebut dikarenakan segmen DNA antara individu bervariasi, memiliki lokasi tertentu dalam kromosom, dan dapat berfungsi sebagai tanda genetik untuk gen yang berhubungan dengan kondisi fisik dan mental tertentu.

Secara psikologis, Q.S. Ali Imran ayat 35 membicarakan tentang masa perkembangan pranatal seorang anak. Perkembangan pranatal terbagi dalam tiga tahapan, yakni tahap germinal, embrionik, dan fetal (Wade \& Tavris, 2007). Tahap germinal dimulai dari pembuahan, saat sperma laki-laki menyatu dengan ovum perempuan, kemudian menjadi zigot. Dua minggu setelahnya tahap embrionik dimulai, dan dilanjutkan dengan tahap fetal setelah minggu kedelapan, pada tahap fetal, organisme disebut sebagai janin (fetus) ditandai dengan mulai menampakkan perkembangan organ dan sistem yang sempurna. Ketiga tahap tersebut terjadi 
selama kurang lebih sembilan bulan dan terjadi proses pencampuran gen antara gen ayah dan ibu (Wade \& Tavris, 2007).

Dikarenakan kedua orang tua Maryam memiliki akhlak serta berkepribadian baik ketika Maryam berada di dalam perut ibunya, maka Maryam sebagai anak pun mewarisi gen dari keduanya untuk menjadi anak yang berakhlak dan berkepribadian yang baik pula. Hal itu sebagaimana menurut Wade \& Tavris (2007) yang mengemukakan bahwa tempermen awal merupakan indikator yang kuat dan konsisiten dalam memperkirakan trait kepribadian pada masa dewasa. Berdasarkan pernyataan tersebut, maka salah satu metode pendidikan anak perempuan masa pranatal adalah dengan menjadi orang tua yang memiliki akhlak mulia, rajin beribadah dan berdo'a selama anak berada di dalam kandungan. Dapat dikatakan bahwa, jika orang tua menginginkan bayi perempuan dalam kandungan ibunya kelak menjadi anak shalihah yang berakhlak mulia, maka kedua orang tuanya patut menjadi pribadi yang shalih, taat, dan bertaqwa kepada Allah, menjaga diri dari perilaku maksiat, jahat dan munkarat selama anak tersebut berada dalam kandungan.

Sebaliknya, jika selama mengandung, seorang ibu maupun ayah melakukan perbuatan jahat, tidak berakhlak baik, maka hal tersebut juga akan berpengaruh pada proses perkembangan pranatal seorang anak. (Wade \& Tavris, 2007) menjelaskan bahwa orang tua terkhusus sang ibu yang menderita penyakit menular seksual (seperti HIV AIDS dan yang lain) dapat menyebabkan janinnya mengalami keterbatasan mental, kebutaan, dan gangguan fisik lainnya. Selain penyakit seksual, seorang ibu yang merokok saat hamil juga menurut Wade \& Tavris (2007) dapat mengakibatkan detak jantung janin abnormal, kelahiran prematur, serta bayi memiliki berat badan yang kurang. Ikonomidou (Wade \& Tavris, 2007) menambahkan, seorang ibu yang mengkonsumsi alkohol dapat membunuh neuron sepanjang perkembangan otak fetus dan dapat merusak kemampuan mental rentang perhatian serta pencapaian akademik anak nantinya. Hasil penelitian menunjukkan bahwa, seorang ibu yang meminum lebih dari dua gelas minuman beralkohol setiap hari secara signifikan meningkatkan resiko Fetal Alcohol Syndrome (FAS), yang diasosiasikan dengan berat lahir rendah, ukuran otak yang lebih kecil, cacat wajah, kurangnya kemampuan koordinasi, dan keterbelakangan mental. Lester, Lagasse, dan Seifer (Wade \& Tavris, 2007) juga menambahkan seorang ibu pengonsumsi narkoba, seperti kokain dapat menyebabkan gangguan pada kemampuan kognitif, bahasa, serta menderita gangguan parah dalam kemampuan mengelola dorongan dan perasaan frustasi anak.

Dengan demikian, maka bagaimana keadaan psikis, serta keadaan moral dan akhlak orang tua, khususnya seorang ibu dapat mempengaruhi perkembangan janin yang dikandungnya. Oleh karena itu, untuk menjaga kemaslahatan pendidikan (tarbiyah) janin yang ada di dalam kandungan, maka menjadi orang tua yang shalih merupakan persyaratan utama.

\section{Analisis Semiotika Q.S. Ali Imran Ayat} 36

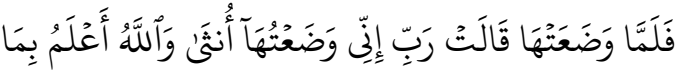

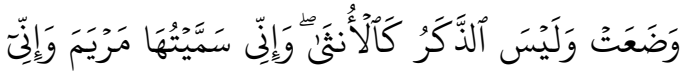

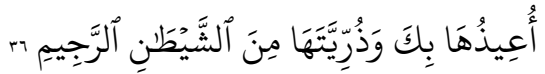

"Maka tatkala istri 'Imran melahirkan anaknya, dia pun berkata: 'Ya Tuhanku, sesunguhnya aku melahirkannya seorang anak perempuan; dan Allah lebih mengetahui apa yang dilahirkannya itu; dan anak laki-laki tidaklah seperti anak perempuan. Sesungguhnya aku telah menamai dia Maryam dan aku mohon perlindungan untuknya serta anak keturunannya kepada (pemeliharaan) Engkau daripada syaitan yang terkutuk'"

Klausa Rabbi inni> wad?a'tuha>

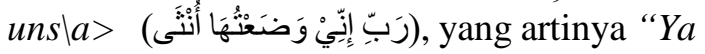
Tuhanku, sesungguhnya aku telah melahirkannya seorang anak perempuan" merupakan perkataan dari istri Imran ketika 
selesai persalinan. Klausa tersebut merupakan tanda yang berfungsi sebagai berita bahwa istri Imran kecewa karena anak yang dilahirkannya tidak sesuai dengan yang diharapkannya, yaitu melahirkan anak lakilaki. Dalam kajian ilmu Balagah, klausa Rabbi inni $>$ wad\} a 'tuha $>$ uns $\backslash a>$ merupakan us\}lub kalam khabari (berita) yang mempunyai tanda atau fungsi untuk iz\} $h a>r u$ al-Tahassuri 'ala syain mahbu $>b$ (memperlihatkan kekecewaan atas sesuatu yang dicintai) (Al-Hasyimi, 2012).

Setelah istri Imran mengungkapkan kekecewaan atas apa yang telah terjadi, ia melanjutkan penjelasan bahwa anak laki-laki dan perempuan itu berbeda. Ungkapan yang digunakan oleh istri Imran adalah wa laisa

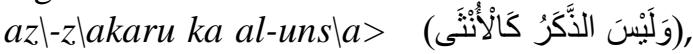
yang artinya "Dan anak laki-laki tidaklah seperti anak perempuan". Pada klausa tersebut penyebutaan azl-zlakar (laki-laki) didahulukan dibandingkan dengan al-uns〈a> (perempuan), yakni istri Imran tidak mengatakan wa laisat al-unsła $>$ ka al-zlakari (dan anak perempuan tidaklah seperti anak laki-laki). Hal ini merupakan tanda bahwa yang diinginkkan dan diharapkan oleh istri Imran itu adalah anak laki-laki, bukan anak perempuan. Selain itu, urutan penyebutan kata al-zlakaru (laki-laki) yang mendahului kata al-uns $\backslash$ > (perempuan) tersebut juga mempunyai tanda bahwa anak laki-laki lebih bisa mewujudkan apa yang telah istri Imran nazarkan dibandingkan dengan anak perempuan.

Kalimat wa inni> sammaituha>

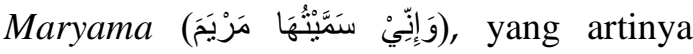
"Sesungguhnya aku telah menamai dia Maryam" juga memiliki tanda yang perlu diperhatikan. Kata sammaituha> (aku telah menamainya) memliki tanda bahwa yang menamai Maryam setelah kelahirannya adalah istri Imran sendiri tanpa suaminya, dan juga menandakan Imran telah wafat sebelum Maryam dilahirkan. Istri Imran menamai anak yang ia lahirkan dengan nama Maryam. Kata Maryam dalam bahasa istri Imran mempunyai makna 'a>bidah (عَابِدَ) yang berarti wanita ahli ibadah (Al-Fad \}l, 2006). Penamaan ini mempunyai tanda bahwa istri Imran mengharapakan anak perempuannya kelak menjadi wanita yang bertaqwa dan taat beribadah. Istri Imran memberikan nama yang terbaik bagi anak perempuannya disebabkan nama dapat membawa pengaruh pada anak yang diberi nama. Jika nama yang diberikan bermakna baik tentu pengaruhnya akan baik pada seorang anak.

Kalimat setelahnya, yakni wa inni> u'iz\uha> bika wa z\urriyyataha min as-

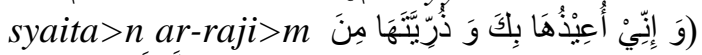
(الثشَيْنَانِ الرَّجِيْر) di dalamnya terdapat beberapa tanda. Klausa wa inni> u'iz وَ إِتّيْ أُعِيْذُهَا yang memiliki arti "Aku mohon perlindungan untuknya", merupakan 'at jaf (sambungan) dari perkataan istri Imran sebelumnya, yaitu klausa inni $>$ wad' $a$ 'tuha $>$ (sesungguhnya aku telah melahirkannya) dan inni $>$ sammaituha> (aku telah menamainya). Ungkapan $u$ 'iz $\backslash u h a>$ yang menggunakan $f i$ 'il muda>ri' (kata kerja yang menunjukkan waktu suatu kejadian yang sedang atau akan terjadi), mempunyai tanda bahwa permohonan perlindungan istri Imran untuk Maryam tersebut merupakan permohonan untuk perlindungan yang berkesinabungan tanpa terputus. Adapun ungkapan wad; $a^{\prime}$ tuha $>$ dan sammaituh $>a$ yang diungkapkan dengan menggunakan fi'il $m a>d\} i$ (kata kerja lampau) memiliki tanda bahwa persalinan dan penamaan pada seorang anak hanya berlangsung sekali saja dan tidak terjadi berulang kali. Huruf إِ yang berturut-turut disertakan dalam tiga kata kerja tersebut berfungsi sebagai at-taukid (penguatan). Sehingga, penggunaan kata إنِّيْ yang artinya "Sesungguhnya aku" pada setiap kata kerja tersebut menandakan bahwa Hannalah yang benar-benar melahirkan Maryam, Hannalah yang benar-benar menamakannya dengan nama Maryam sebagai do'a untuknya, serta Hannahlah yang bersungguh-sungguh meminta perlindungan atas Maryam dan cucunya kelak.

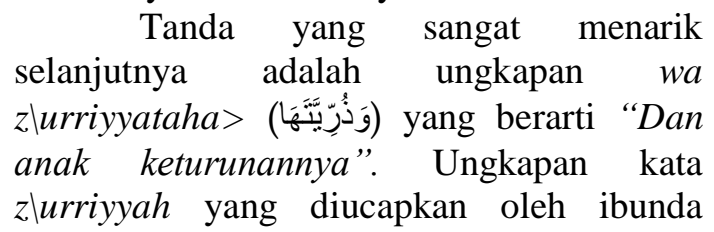


Maryam dalam bentuk tunggal (bukan jamak) ini mengandung tanda bahwa ia telah mengetahui perihal Maryam yang akan melahirkan seorang anak tanpa adanya seorang suami dengan izin Allah, sehingga ia pun memohon perlindungan kepada Allah untuk Maryam dan anaknya dengan perlindungan yang berkesinambungan.

Secara umum, Q.S. Ali Imran ayat 36 ini berbicara tentang tahap perkembangan post-natal (setelah kelahiran) seorang Maryam. Walaupun semulanya Hannah merasa kecewa karena anak yang dilahirkannya ternyata perempuan, ia tetap mengadukan hal tersebut pertama-tama kepada Allah sebagai bentuk penghambaan kepada-Nya, sehingga ia pun menerima takdir Allah itu dengan langsung menamakan anak perempuan yang dilahirkannya dengan nama Maryam. Dengan nama tersebut Hannah berharap kelak putrinya menjadi seorang hamba yang taat kepada-Nya dalam beribadah. Di antara fungsi nama adalah sebagai do'a dan harapan. Karena nama yang baik akan menjadi motivasi bagi sang anak untuk menjadi anak yang baik, dan bahwa memang namanya sesuai dengan apa yang ada pada dirinya. Diasumsikan bahwa jika Hannah berlarut dalam rasa kecewanya, maka tidaklah mungkin ia segera memberi nama yang baik kepada putrinya, yakni bisa saja ia membiarkan anak tersebut terlantar begitu saja karena tidak sesuai dengan harapannya. Begitupula jika Hannah tidak menerimanya dan mendo'akannya serta memberikan pendidikan yang baik, maka Maryam akan tumbuh menjadi hamba dan pribadi yang tidak mengenal siapa Tuhannya, buruk akhlaknya, bahkan tidak beriman kepada Allah sebagai penciptanya. Namun demikian, karena ketaatan, ketaqwaan, serta keberserahan dirinya kepada Allahlah yang membuat ia segera menghapus kekecewaannya dan menerima anak tersebut dengan murah hati dan bahagia.

Prinsip Hannah tersebut relevan dengan pernyataan Rasulullah yang menyatakan setiap anak lahir dalam keadaan fitrah, yakni bersih dan suci, dan tergantung daripada didikan dan ajaran dari orang tuanya. Karena orang tua sebagai lingkungan pertama seorang anak, maka orangtualah yang menentukan mau dibawa kemana arah hidup anaknya tersebut. Diriwayatkan dari Abu Hurairah, bahwasannya Rasulullah shallallahu 'alaihi wasallam bersabda:

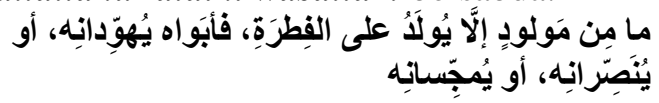

"Seorang bayi tak dilahirkan (ke dunia ini) melainkan ia berada dalam kesucian (fitrah). Kemudian kedua orang tuanyalah yang akan membuatnya menjadi Yahudi, Nasrani, ataupun Majusi". (H.R. Bukhari, dengan derajat shahih dalam Shahih Bukhari 4775).

Hadis tersebut menunjukkan pentingnya pendidikan pasca lahir dari orang tua terhadap anak-anaknya. Seorang wanita yang melahirkan anak perempuan yang tidak sesuai harapannya, seperti berjenis kelamin berbeda, atau mengalami kecacatan fisik maupun mental, ia harus menerima kehadiran anak itu dengan lapang dada, mendidiknya dengan pemahaman agama yang baik, serta membimbingnya menjadi pribadi yang berakhlak mulia. Tidak sekali-kali membencinya, lalu membuangnya, memberikan kepada orang lain, ataupun menelantarkannya dengan anggapan anak tersebut membuat malu keluarganya atau merepotkannya dari segi materi, apalagi membunuhnya. Sebagai anak yang terlahir dalam keadaan fitrah, baik dalam kondisi sehat maupun sakit, sudah menjadi kewajiban setiap orang tua untuk menerima dan mendidiknya dengan pendidikan yang baik.

Selain menerima kehadiran Maryam sebagai anak perempuan kemudian memberinya nama yang baik, Hannah juga menerapkan suatu metode yang luar biasa dalam pendidikan anak perempuan sesaat setelah kelahirannya, yakni meminta perlindungan kepada Allah untuk melindungi Maryam dan keturunannya dari syaitan yang terkutuk. Syaitan yang rajanya adalah iblis sebagai mahluk Allah yang menentang perintah Allah untuk sujud kepada Nabi Adam telah membuat suatu perjanjian khusus dengan Allah atas anak cucu Nabi Adam. Perjanjian tersebut tercantum dalam Q.S. AlA'raf: 16-17, yang artinya: "(Iblis) 
menjawab, 'Karena Engkau telah menyesatkan aku, pasti aku akan selalu menghalangi mereka dari jalan-Mu yang lurus, kemudian pasti aku akan mendatangi mereka dari depan, dari belakang, dari kanan, dan dari kiri mereka. Dan Engkau tidak akan mendapati kebanyakan mereka bersyukur'”.

Hannah dalam hal ini jelas sekali mengetahui bahwa putrinya juga merupakan keturunan Nabi Adam, sehingga sangat mungkin bagi Maryam untuk juga diganggu dan dihalangi oleh iblis dalam beribadah selama ia hidup, mengingat Maryam adalah seorang anak perempuan. Oleh karena Hannah tidak ingin iblis melakukan hal tersebut kepada putrinya, sehingga setelah menamainya ia langsung meminta perlindungan kepada Allah dari segala bentuk gangguan, godaan, dan halangan yang dilakukan oleh iblis dan semua bala tentaranya. Selain kepada Maryam, Hannah juga meminta perlindungan kepada Allah atas cucunya yang kelak lahir dari rahim putrinya. Perlindungan yang diminta Hannah langsung kepada Allah adalah perlindungan yang bersifat berkesinabungan atau selamalamanya, dengan harapan agar selama masa hidup Maryam dan putranya selalu terjaga dari iblis. Mendengar permintaan perlindungan Hannah tersebut Allah pun segera mengabulkannya tanpa syarat apapun. Hal itu kemudian diperjelaskan oleh Rasulullah bahwa Allah benar-benar melindungi Maryam dan putranya sejak dilahirkan ke alam dunia. Dalam hadis yang diriwayatkan oleh Abu Hurairah, bahwa Rasulullah shallallahu 'alaihi wasallam bersabda:

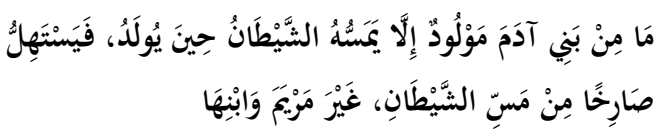

"Setiap anak manusia pasti diganggu setan ketika dia dilahirkan, sehingga dia teriak menangis, karena disentuh setan. Kecuali Maryam dan putranya." (HR. Bukhari dengan derajat shahih dalam shahih Bukhari 3431).

Godaan syaitan dapat dilakukan dalam berbagai macam bentuk, seperti merayu seseorang hingga keluar dari keimanannya, berbuat kesyirikan, berbuat maksiat, berzina, dan lain sebagainya. Bentuk perlindungan Allah kepada Maryam sebagai kemurahan hatinya mengabulkan do'a Hannah juga terbukti dalam keterjagaannya Maryam dari perilaku zina, yang merupakan salah satu dari godaan syaitan. Pernyataan yang menjadi bukti atas hal tersebut termaktub dalam perkataan Maryam di dalam Firman-Nya, yang artinya: "Dia (Maryam) berkata bagaimana mungkin aku mempunyai anak laki-laki, padahal tidak pernah ada seorangpun dari laki-laki yang menyentuhku, dan aku bukan seorang pezina" (Q.S. Maryam: 20).

Ayat tersebut menandakan bahwa, bahkan sampai dewasa Maryam tidak pernah sekalipun disentuh oleh seorang laki-laki yang bukan mahramnya, terlebih lagi melakukan perzinahan. Dengan demikian, maka pentingnya metode ini untuk dipraktekkan seluruh orang tua yang baru saja melahirkan seorang anak, terutama anak perempuan.

\section{Analisis Semiotika Q.S. Ali Imran Ayat} 37

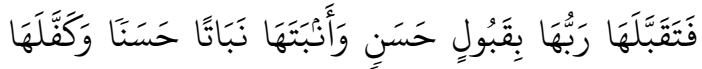

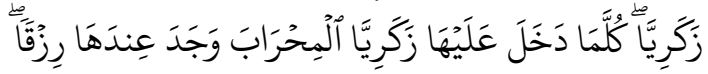

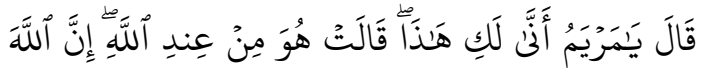

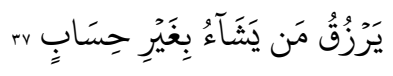

"Maka Tuhannya menerimanya (sebagai nazar) dengan penerimaan yang baik, dan mendidiknya dengan pendidikan yang baik dan Allah menjadikan Zakariya pemeliharanya. Setiap Zakariya masuk untuk menemui Maryam di mihrab, ia dapati makanan di sisinya. Zakariya berkata: 'Hai Maryam dari mana kamu memperoleh (makanan) ini?' Maryam menjawab: 'Makanan itu dari sisi Allah'. Sesungguhnya Allah memberi rezeki kepada siapa yang dikehendaki-Nya tanpa hisab."

Pada klausa wa anbataha> naba>tan hasanan (وَأَنْبَنَها نَبَانَاً حَسَنَاً ) yang artinya "Dan Dia (Allah) membesarkannya 
dengan pertumbuhan yang baik", terdapat tanda bahwa Allah memelihara Maryam seperti halnya memelihara tumbuhan, sehingga tumbuhan tersebut tumbuh dengan pertumbuhan yang baik. Gaya bahasa pada ungkapan wa anbataha $>$ merupakan $u s l u>b$ maja>z mursal. Ungkapan anbataha> merupakan majaz dari ungkapan tarbiyyataha> bima> yas\}luhuha> fi>

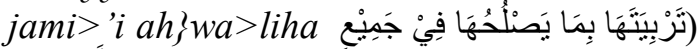
أَحْوَ الِِهَا) yang artinya pendidikan yang baik baginya dalam segala hal (S \}a>fi, 1995). Allah menyerupakan Maryam dengan tumbuhan, karena baik Maryam maupun tumbuhan butuh terhadap perawatan yang baik, penjagaan dari segala penyakit, dan perlindungan dari segala hal yang bisa merusak.

Allah memelihara Maryam dengan tangan Nabi Zakariya. Untuk itulah dalam ayat ini Allah menggunakan fi'il kaffala. Kata

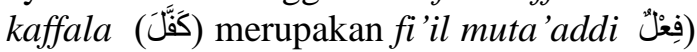

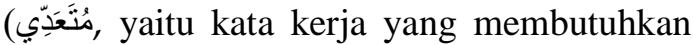
objek. Fi'il kaffala adalah termasuk kata kerja yang bermakna pemindahan, yakni Allah memindahkan hak pemeliharaan atas Maryam yang seharusnya dilakukan oleh orang tuanya kepada Zakariya.

Kata Mihra>b (مِحَرَابٌ) adalah nama tempat berupa sebuah ruangan di Baitul Maqdis yang letak pintunya berada di tengahtengah dinding seperti pintu ka'bah dan ditempati Maryam sebagai tempat untuk beribadah. Mihra $>b$ merupakan isim $m a k a>n$ (kata yang menunjukan tempat) dari fi'il ha-ra-ba (حَرَبَ) yang mempunyai arti berperang, maka secara bahasa mihra $>b$ berarti tempat berperang. Maksud dinamakan dengan kata mihra $>b$ adalah karena tempat tersebut digunakan untuk memerangi syaitan dan hawa nafsu manusia. Berperang dengan cara selalu beribadah dan menjalankan ketaatan kepada Allah. Kata mihra $>b$ mempunyai tanda bahwa di tempat itulah Maryam tumbuh menjadi wanita yang shalihah dan bertaqwa dikarenakan kesehariannya selalu diisi dengan peribadatan dan ketaatan kepada Allah $T a^{\prime} a>l a$.
Secara keseluruhan klausa tersebut, yakni kullama> dakhala 'alaiha> Zakariya

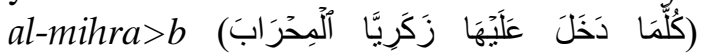
mempunyai tanda mengenai waktu Zakariya memasuki mihra $>b$. Kata kullama $>$ dakhala (كُلََّا دَخَلَ) mempunyai tanda bahwa masuknya Zakariya ke dalam mihra $>b$ bukan hanya sekali saja, melainkan berulang kali. Kemudian ungkapan 'alaiha (عَلَيَهَا) mempunyai tanda tersendiri, yaitu menunjukkan adanya sesuatu yang tinggi. Maksud tinggi di sini adalah letak mihra $>b$ yang digunakan Maryam untuk beribadah itu berada dalam ketinggian dan harus menggunakan tangga ketika ingin memasukinya. Kata L kali" dalam ayat ini juga menandakan setiap kali Zakariya memasuki mihrab Maryam dan mendapati rizki di sisi Maryam, ia selalu menanyakan asal muasal rizki itu, dan Maryam telah menjawab itu dari Allah, namun ia tetap menanyakan hal tersebut dengan pertanyaan yang sama. Hal demikian menujukkan, pada pertemuan Zakariya yang kedua dan seterusnya dengan Maryam ia telah mengetahui bahwa rizki itu pasti dari Allah.

Setiap kali Zakariya memasuki mihra $>b$ yang Maryam berada di dalamnya, ia mendapati rizki di sisi Maryam. Kata rizqa > difirmankan oleh Allah menggunakan

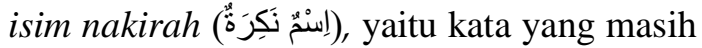
belum jelas bendanya atau masih umum. Penggunaan isim nakirah pada kata rizqa> memberi tanda bahwa rizki tersebut tidak hanya dalam satu jenis melainkan dari berbagai jenis. Hal itu dikarenakan isim nakirah menghendaki adanya jumlah yang tidak sedikit (Muhammad, 1993). Kata rizqun banyak ahli yang menafsirkan sebagai makanan yang berbentuk buah-buahan.

Ketika Zakariya mendapati adanya rizki di sisi Maryam, ia bertanya dengan

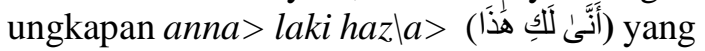
artinya "Dari mana engkau memperoleh ini?”. Ungkapan anna> laki hazla> mempunyai tanda bahwasanya Zakariya merasa aneh dengan adanya sesuatu di sisi Maryam, karena tidak hanya sekali, melainkan berulang kali setiap menemui 
Maryam di dalam mihrab ia mendapati hal tersebut. Ungkapan ini juga menandakan adanya kekhawatiran dalam diri Zakariya. Zakariya khawatir jika rizki tersebut berasal dari orang lain selain dirinya yang masuk mihrab menemui Maryam. Kata anna $>$ pada ungkapan anna> laki hazla> mengandung pertanyaan mengenai cara, tempat, dan waktu. Tetapi pada ungkapan ini, kata anna> mengandung pertanyaan mengenai asal-muasal rizki tersebut. Adapun kata $h a z l a>$ yang digunakan pada pertanyaan ini menunjuk pada rizki yang berada di sisi Maryam saat itu.

Ungkapan huwa min 'indilla $>h$ هُ (هو )

مِنْ عِنْدِ اللَّهِ yang artinya "Itu dari sisi Allah" adalah jawaban yang dilontarkan Maryam atas pertanyaan Zakariya. Klausa ini juga sebagai tanda bahwa pada saat itu rizki tersebut bukan berasal dari manusia, dan sekaligus sebagai penghilang kekhawatiran yang ada pada diri Zakariya.

Ketika Hannah telah menyelesaikan persalinan Maryam, ia membawa bayi tersebut kepada para pemuka Bani Israil, dan mengatakan kepada mereka, "Ini adalah anak perempuanku, aku telah bernazar agar ia berkhidmat kepada Baitul Maqdis, maka hendaklah salah satu di antara kalian bersedia untuk mengasuh dan mendidiknya" (Muhammad, 1993). Maryam lahir dari kedua orang tua yang dikenal dengan keluarga Imran (Ali Imran), yaitu keluarga yang amat disegani oleh Bani Israil dan dikenal dengan keluarga yang shalih. Ketika orang tua Maryam tidak bisa sepenuhnya mendidiknya karena suatu nazar yang wajib dilaksanakan, maka Allah memilih Zakariya sebagai orang yang penanya justru bergerak melawan arus air, sehingga Zakariyalah yang berhak mengasuh dan mendidik Maryam. Zakariya adalah pemimpin dan penghulu Bani Israil, orang yang paling alim di antara mereka, serta imam dan Nabi mereka (Isma>il, 1999).

Pemeliharaan Maryam oleh Zakariya merupakan ketentuan dari Allah $T a^{\prime} a>l a$, sehingga melalui Nabi Zakariyalah Maryam tumbuh dalam ketaatan dan ketaqwaan kepada-Nya. Pemilihan Zakariya sebagai pemelihara Maryam mempunyai tanda bahwa dalam pendidikan anak perempuan terdapat hal-hal pokok yang harus diperhatikan, yaitu orang tua yang baik dan pendidik laki-laki yang baik. Dengan demikian dapat dikatakan bahwa ketika seorang anak perempuan lahir dari keluarga yang baik dan di didik oleh seorang ayah dan pendidik yang baik, maka pertumbuhan serta perkembangan jiwa anak itupun akan menjadi baik pula.

Maryam tumbuh dewasa di bawah asuhan dan didikan Zakariya, serta menjadi wanita ahli ibadah yang tumbuh dengan pertumbuhan yang baik. Lingkungan Baitul Maqdis merupakan lingkungan yang baik untuk Maryam tumbuh besar, karena di dalamnya ia banyak belajar kepada hambahamba Allah yang sholeh, ia belajar ilmu, kebaikan, dan agama. Dengan demikian, pelajaran selanjutnya yang dapat dipetik dari perilaku Hannah yang membawa Maryam ke Baitul Maqdis adalah pemberian lingkungan tempat tinggal maupun lingkungan sekolah yang baik oleh kedua orang tua terhadap anak perempuannya, agar anaknya dapat tumbuh dan berkembang dengan baik. Hal itu dikarenakan lingkungan mempunyai pengaruh sangat besar dalam membentuk dan menentukan perubahan sikap dan perilaku seseorang, terutama pada generasi muda dan anak-anak. Dalam bukunya, Wade dan Tavris (2007) menyatakan bahwa lingkungan dapat mempengaruhi kepribadian seorang anak. Artinya, jika suatu lingkungan itu baik, maka baik pula kepribadian seorang anak, dan sebaliknya jika lingkungan itu buruk, maka secara signifikan anak tersebut akan buruk pula. Selain itu, perilaku Hannah tersebut juga menandakan bahwa, walaupun ketika berada di dalam kandungan orang tua sudah selalu mendo'akan janinnya, meniatkan niat yang baik dalam mendidik anaknya, setelah lahir disusul dengan mendo'akannya dengan memberi nama yang baik, serta meminta perlindungan atasnya dari syaitan, namun jika tidak diiringi dengan usaha pemberian lingkungan belajar yang baik, maka anak tersebut belum tentu akan menjadi baik hingga dewasa. Lingkungan sekolah dan 
tempat tinggal yang baik perspektif Islam merupakan lingkungan yang di dalamnya ditegakkan nilai-nilai ketuhanan dan nilainilai keislaman.

Para orang tua juga harus selalu menjaga anak-anak perempuannya dari pengaruh buruk sebuah lingkungan dan pergaulan agar mereka tumbuh dengan pertumbuhan yang baik (naba>t hasan) sebagaimana bertumbuhnya Maryam. Wade dan Tavris (2007) menyatakan, saat seorang anak meninggalkan rumah, yakni mulai bersekolah, pengaruh orang tua terhadap perilaku anak di luar rumah mulai menurun, sehingga saat itulah teman sebaya, kejadiankejadian yang kebetulan, dan berbagai situasi unik mulai mengambil alih pembentukan karakter dan kepribadiannya.

Maryam tumbuh dengan

pertumbuhan yang baik dalam pengawasan Allah. Salah satu hal yang berpengaruh terhadap pertumbuhan yang baik tersebut yaitu Maryam selalu mendapatkan makanan yang halal lagi baik (t)ayyib), yang digambarkan dengan kata rizqan dalam AlQur'an. Makanan merupakan unsur penting yang bisa mempengaruhi sifat dan karakter seorang anak. Baik buruknya sikap dan karakter seorang anak perempuan juga dipengaruhi oleh asupan makanan yang diberikan oleh orang tuanya. Untuk itu, sudah menjadi kewajiban para orang tua agar menafkahi anak perempuannya dengan rizki yang halal lagi baik (t)ayyib), agar mereka tidak mempunyai perangai dan tingkah laku yang buruk. Dari Jabir radhiallahu 'anhu bahwasanya Rasulullah shallallahu 'alaihi wa sallam bersabda:

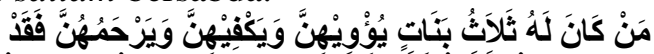

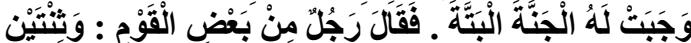

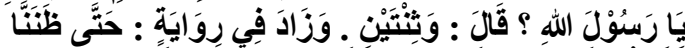

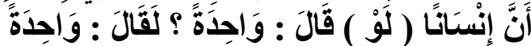

"Barangsiapa yang memiliki tiga anak perempuan, ia mengayomi mereka, mencukupi mereka, dan menyayangi mereka maka tentu telah wajib baginya surga". Maka ada salah seorang dari kaum berkata, "Kalau dua anak perempuan Ya Rasulullah?". Nabi berkata, "Dua anak perempuan juga" Dalam riwayat lain ada tambahan, "Sampai-sampai kami menyangka kalau ada orang yang berkata, "Kalau satu anak perempuan?", maka tentu Nabi akan berkata, "Satu anak perempuan juga". (Dihasankan oleh AlAlbani dalam As-Shahihah no 1027, dan dishohihkan ooleh Muslim).

Hadis tersebut menunjukkan pentingnya nafkah berupa sandang, pangan, dan papan bagi setiap anak, terutama anak perempuan. Adapun ayat yang menceritakan Maryam selalu mendapatkan rizki dari Allah menunjukkan bahwa kebutuhan dasar utama seorang manusia adalah makan dan minum. Sebagaimana hierarki kebutuhan Maslow yang meletakkan kebutuhan fisiologis sebagai kebutuhan paling mendasar bagi manusia, maka kebutuhan tersebut dikatakan sebagai kebutuhan terpenting yang harus dipenuhi terlebih dahulu dari pada semua kebutuhan yang lain (Schultz \& Schultz, 2013). Selain rizki berupa makanan dapat memberikan energi pada tubuh Maryam untuk semakin giat beribadah, buah-buahan yang disediakan Allah untuk Maryam juga menandakan pentingnya mengonsumsi buah bagi anak perempuan di setiap harinya agar semakin tumbuh cerdas dan memiliki kulit serta wajah yang indah.

Kecerdasan atau bahasa psikologinya disebut sebagai inteligensi merupakan salah satu elemen psikologi kognitif. Wade dan Tavris (2007) mendefinisikan inteligensi sebagai suatu karakteristik dalam diri seseorang yang didapatkan melalui penalaran, kemampuan untuk mengambil keuntungan dari suatu pengalaman, memperoleh pengetahuan, berpikir secara abstrak, bertindak berdasarkan alasan, dan beradaptasi terhadap adaptasi yang terjadi pada lingkungan. Hasil penelitian yang dilakukan oleh University of Eastern Finland, mendapati anak-anak yang mengonsumsi buah dan sayuran, dalam tiga tahun pertama sekolah memiliki kecerdasan yang lebih baik dibandingkan yang tidak mengonsumsi (Priherdityo, 2016).

Terpilihnya Zakariya sebagai pengasuh Maryam sejak masih bayi memiliki tanda bahwa Allah sengaja memilih sosok laki-laki yang shaleh dan berilmu untuk 
berperan sebagai ayah dalam pendidikan dan pengasuhan Maryam. Hal itu dikarenaakan ketika Maryam lahir, ayahnya yakni Imran telah meninggal dunia. Bisa saja penghuni Baitul Maqdis yang mengasuh Maryam adalah seorang wanita, namun dalam hal ini Allah secara langsung mengangkat Zakariya yang diberi amanah mengasuhnya. Dengan demikian, dapat dikatakan bahwa Zakariya memiliki peran sebagai guru dan pendidik sekaligus sebagai ayah Maryam. Peristiwa tersebut memberi makna secara luas tentang pentingnya kehadiran seorang ayah dalam proses pendidikan dan tumbuh kembang anak perempuan sejak dilahirkan.

Hasil-hasil penelitian terkait pengaruh dan pentingnya peran seorang ayah dalam pendidikan dan pengasuhan anak perempuan, di antaranya adalah (Allen \& Daly, 2007): a. Pengaruh pada perkembangan kognitif, penelitian pada anak usia sekolah menghasilkan bahwa anak dengan ayah yang terlibat dalam pengasuhan lebih sedikit yang mengalami problem perilaku di sekolah, mempunyai ketrampilan kuantitatif dan verbal, menunjukkan fungsi/kemampuan kognitif yang lebih tinggi, mampu memecahkan masalah secara lebih baik, dan menunjukkan IQ yang lebih tinggi; b. Pengaruh pada perkembangan emosional, hasil penelitian menunjukkan anak dengan peran ayah pada pendidikannya lebih tahan ketika menghadapi situasi yang penuh tekanan emosional, lebih sedikit depresi, penuh perhatian ketika berhadapan dengan masalah, lebih dapat mengatur emosi dan impuls-impuls secara adaptif, dapat melakukan kontrol diri, dan lebih sedikit yang menunjukkan impulsivitas; c. Pengaruh pada perkembangan sosial, hasil menunjukkan keterlibatan ayah secara positif berhubungan dengan kompetensi sosial anak, mempunyai hubungan dengan teman sebaya yang positif serta minim agresivitas ataupun konflik, menunjukkan interaksi yang bersifat prososial, menunjukkan lebih sedikit reaksi emosi negatif atau pun ketegangan selama bermain dengan teman sebaya, lebih toleran dan mempunyai kemampuan untuk memahami, dapat bersosialisasi dengan baik, dalam jangka panjang menjadi orang dewasa yang sukses, berhasil dalam pernikahan, anak mempunyai pertemanan yang awet (mampu bertahan lama), dan dapat menyesuaikan diri dengan sekolah, baik secara personal maupun secara sosial; d. Pengaruh pada penurunan perkembangan anak yang negatif, hasil penelitian menunjukkan keterlibatan ayah melindungi anak dari perilaku penggunaan obat-obatan terlarang di masa remaja, perilaku membolos, mencuri, minumminuman keras, dan rendahnya frekuensi externalizing dan internalizing symptom seperti perilaku merusak, depresi, dan berbohong.

Berdasarkan paparan hasil-hasil penelitian tersebut, maka secara keseluruhan dapat peneliti katakan, pemilihan Zakariya sebagai pengasuh Maryam memiliki tanda bahwa Allah hendak mendidik Maryam melalui tangan seorang lelaki sholeh. Melalui Zakariya, Allah ingin mempersiapkan Maryam secara matang, baik dari aspek kognitif, emosional, maupun sosial dalam menghadapi ujian besar yang akan terjadi di masa dewasanya berupa mengandung serta melahirkan seorang anak laki-laki tanpa disentuh dan dinikahi oleh seorang lelaki.

Adapun metode pendidikan Zakariya terhadap Maryam digambarkan dalam alQur'an berupa dialognya dengan Maryam. Dialog tersebut adalah ketika Zakariya melihat adanya rizki di sisi Maryam, ia pun bertanya sebagai tanda perhatian, peduli, dan khawatirnya kepada Maryam "Hai Maryam dari mana kamu memperoleh (makanan) ini" (Q.S. Ali Imran [3]: 37). Mendengar pertanyaan tersebut, Maryam pun menjawab "Makanan itu dari sisi Allah. Sesungguhnya Allah memberi rezeki kepada siapa yang dikehendaki-Nya tanpa hisab" (Q.S. Ali Imran [3]: 37). Metode dialog tersebut menunjukkan bahwa seorang ayah sebagai pendidik utama maupun seorang guru tidak sepatutnya memarahi seorang anak khususnya anak perempuan sebelum menanyakan kebenarannya kepada sang anak, apalagi memukulnya setelah mengetahui sang anak memiliki sesuatu yang belum diketahui sumbernya oleh seorang 
ayah maupun guru. Yang harus dilakukan adalah menanyakan terlebih dahulu asal muasal sesuatu yang dimiliki seorang anak tersebut, lalu mendengarkan jawabannya. Jika ternyata sesuatu yang dimiliki anak bersumber dari arah yang tidak jelas, maka bagi ayah dan pendidik untuk mengarahkan dan menasehatinya agar mengembalikan barang yang bukan miliknya tersebut kepada sumbernya. Metode Zakariya ini juga mempunyai makna, walaupun seorang ayah maupun guru telah mengetahui sumber dari sesuatu yang dimiliki seorang anak adalah berasal dari arah dan jalan yang benar, namun mereka sepatutnya tetap menanyakannya kepada sang anak sebagai bentuk kepedulian dan rasa perhatian kepadanya. Hal demikian akan menumbuhkan pada sang anak sikap patuh, merasa dipedulikan dan disayang, merasa diperhatikan, sehingga dapat menjadikannya pribadi yang berhati-hati dalam segala hal yang belum diketahui sumbernya secara jelas, menjauhkannya dari sifat mencuri, menipu orang lain, serta berbohong.

Metode pendidikan anak selanjutnya yang diterapkan Zakariya adalah pengawasan terhadap Maryam. Maryam berada sendiri di dalam mihrabnya yang letaknya berada di tempat yang tinggi dari Baitul Maqdis, sehingga untuk mengetahui keadaannya maka Zakariya harus secara berulang naik menemuinya di mihrabnya. Hal yang dilakukan Zakariya tersebut menandakan bahwa ia memang berperan sebagai seorang ayah yang selalu memastikan keadaan putrinya baik-baik saja, mengawasi putrinya dari segala pengaruh buruk yang mengancamnya, serta melindungi putrinya dari segala hal yang haram. Dengan demikian, penerapan metode Zakariya ini secara luas bagi setiap ayah yang memiliki anak perempuan agar selalu mengawasi putrinya di manapun ia berada. Jika putrinya berada satu rumah dengannya, maka bagi sang ayah untuk selalu menanyakan kabarnya, menanyakan apa saja kebutuhannya lalu berusaha mencukupinya, memantau pergaulannya dengan temantemannya, dan menyertainya dalam bepergian. Namun, jika putrinya tersebut berada jauh darinya baik berbeda rumah, kota, pulau, maupun negara, maka bagi sang ayah untuk selalu menanyakan kabarnya, jika berkesempatan maka menjenguknya, menitipkannya pada tetangga yang baik, mengontrol perkembangan pendidikannya, serta menempatkannya di lingkungan tempat tinggal yang baik. Mengenai pengawasan seorang ayah terhadap anak perempuan ini, Abdullah bin Umar radiyallahuanhuma mengatakan bahwa Nabi shallallahu 'alaihi wasallam bersabda: "Kalian semua adalah pemimpin, dan masing masing kalian bertanggung jawab atas orang yang dipimpinnya. Seorang Amir (raja) adalah pemimpin, seorang suami pun pemimpin atas keluarganya, dan isteri juga pemimpin bagi rumah suaminya dan anak-anaknya. Kamu sekalian adalah pemimpin dan kamu sekalian akan diminta pertanggungjawabannya atas kepemimpinannya." (H.R. al-Bukhari no. 893, 5188, 5200 dan Muslim no. 1829).

Berdasarkan hadis tersebut maka pengawasan seorang ayah terhadap putrinya adalah sebagai bentuk tanggung jawabnya kepadanya, sebagaimana Zakariya yang bertanggung jawab sebagai pengasuh Maryam saat itu. Di dalam hadis lain, Rasulullah menegaskan bahwa di antara tanggungjawab tersebut adalah dengan mengayomi setiap anak perempuan yang dimiliki oleh seorang ayah. Hal itu sebagaimana yang diriwayatkan oleh sahabat Anas bin Malik radhiyallahu 'anhu, dia berkata bahwa Rasulullah shallallahu 'alaihi wa sallam bersabda:

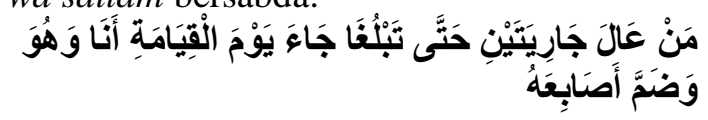

"Barangsiapa yang mengayomi dua anak perempuan hingga dewasa maka ia akan datang pada hari kiamat bersamaku" (Anas bin Malik berkata: Nabi menggabungkan jari-jari jemari beliau). (H.R. Muslim 2631 dan Ibnu Abi Syaibah 25439).

Imam An Nawawi rahimahullah menjelaskan, "Yang dimaksud dengan mengayomi anak perempuan (عَ) adalah menunaikan hak-hak mereka dengan menafkahi, seperti makan, pakaian, 
pendidikan, dan mendidik mereka serta memenuhi kebutuhan-kebutuhan yang lainnya". Selain itu terdapat ganjaran yang besar bagi orangtua yang mengayomi anak perempuan mereka, berupa nikmat surga, terhalangi dari siksa api neraka, dan kedekatan bersama Nabi shallallahu 'alaihi wa sallam di akhirat (Mianoki, 2012).

\section{Kesimpulan}

Kisah Maryam binti Imran dalam AlQur'an ayat 35 sampai 37 mengandung metode pendidikan anak khususnya anak perempuan sejak masa pranatal atau masa dalam kandungan, masa postnatal atau masa kelahiran, hingga masa dalam pengasuhan sejak bayi, anak-anak, hingga dewasa. Masa pranatal dan masa kelahiran Maryam berada di bawah pendidikan ayah dan ibunya, yakni Imran dan Hannah. Adapun masa postnatal pada masa kelahiran Maryam hanya berada di bawah pendidikan ibunya. Sedangkan masa pengasuhan Maryam sejak bayi, anak-anak, hingga dewasanya diambil alih oleh seorang Nabi yang shaleh, yakni Zakariya yang berperan sebagai seseorang pengganti ayahnya Maryam sekaligus guru atau pendidik baginya.

Berdasarkan hasil analisis semiotika terhadap kisah Maryam binti Imran dalam Q.S. Ali Imran ayat 35 dengan perspektif Islam dan psikologis, ditemukan bahwa ayat ini secara umum mengandung metode pendidikan pada anak perempuan ketika berada dalam masa pranatal, yakni masa janin berada di dalam rahim ibu. Di antara metode pendidikan terhadap anak perempuan yang dapat dipetik dari kisah masa pranatal Maryam ini adalah: 1) Bernazar dalam hal kebaikan terhadap anak ketika berada di dalam kandungan. Bagi kedua orang tua, baik suami maupun istri, setelah mengetahui terjadinya kehamilan agar meniatkan untuk memiliki dan mendidik seorang anak sematamata karena Allah serta sebagai bentuk ibadah kepada-Nya dan untuk menjadikan anak tersebut hamba Allah yang senantiasa berkhidmat kepada Allah; 2) Berdo'a untuk kebaikan anak selama berada di dalam kandungan, yang dilakukan oleh kedua pasangan suami istri, terutama sang ibu, karena ucapan do'a sang ibu akan langsung dirasakan dan didengar oleh janinnya; 3) Mengetahui atau tidak jenis kelamin bayi yang sedang dikandung, sebagai orang tua calon buah hati agar selalu dan tetap mendo'akan kebaikan-kebaikan untuknya, memberikan nutrisi asupan makanan maupun minuman sehat yang cukup, serta berpikiran positif terhadap janin yang sedang dikandung; dan 4) Secara genetis, keadaan psikis, serta keadaan moral dan akhlak orang tua, khususnya seorang ibu dapat mempengaruhi perkembangan janin yang dikandungnya, sehingga jika orang tua menginginkan bayi dalam kandungan ibunya kelak menjadi anak shalih, berakhlak mulia, maka kedua orang tuanya patut menjadi pribadi yang shalih, taat, dan bertaqwa kepada Allah, menjaga diri dari perilaku maksiat, jahat dan munkarat.

Secara keseluruhan, hasil analisis semiotika pada Q.S. Ali Imran ayat 36 menyimpulkan bahwa ayat tersebut berisi tentang metode pendidikan pada anak perempuan ketika berada dalam masa postnatal, yakni masa kelahiran ke alam dunia. Di antara metode pendidikan terhadap anak perempuan yang dapat dipetik dari kisah masa postnatal Maryam ini adalah: 1) Bagi setiap orang tua untuk menerima apapun keadaan anak yang dilahirkan baik dari segi fisik, psikis, maupun jenis kelamin dengan senang hati, lapang dada, dan berserah diri kepada Allah walaupun anak tersebut tidak sesuai dengan harapan yang diinginkan. Karena penerimaan saat awal dilahirkan akan mempengaruhi pendidikan orang tua terhadap anak pada tahap selanjutnya. Orang tua yang tidak menerima anaknya cenderung melakukan hal-hal yang tidak manusiawi, dan anak yang merasa tidak diterima atau bahkan tidak diterima oleh orang tuanya cenderung memiliki pendidikan yang buruk di setiap tahap perkembangannya; 2) Pemberian nama yang baik terhadap anak, berupa nama yang mengandung do'a kebaikan untuknya, sebagaimana Hannah yang menamai putrinya Maryam yang berarti seorang wanita ahli ibadah; 3) Mendo'akan 
kebaikan untuk sang anak sesaat setelah kelahirannya; 4) Meminta perlindungan kepada Allah sesaat setelah kelahiran sang anak dari gangguan dan godaan syaitan yang terkutuk. Sebagaimana permintaan perlindungan kepada Allah oleh Hannah atas Maryam dalam firman-Nya, maka setiap ibu dan ayah dapat mengucapkan "Alla > humma inni> u'i>zu ibni>/binti> bika minasysyait\}a>nirraji $>m$ ", yang artinya "Yaa Allah, sesungguhnya aku memohon perlindungan-Mu untuk anak lakilakiku/anak perempuanku dari gangguan syaitan yang terkutuk".

Demikian menurut analisis peneliti, dengan menerapkan metode-metode yang terkandung dalam ayat 35 dan 36 terhadap anak perempuan sejak berada di dalam kandungan, maka diharapkan setiap anak perempuan akan terlindung dan terhindar dari kekerasan apapun, baik fisik, seksual, maupun moral ketika menjalani masa anakanak hingga dewasa.

Sesuai hasil analisis semiotika terhadap kisah Maryam dalam Q.S. Ali Imran ayat 37 , dapat peneliti simpulkan bahwa ayat tersebut mengandung metode pendidikan pada anak perempuan ketika berada dalam masa pengasuhan baik orang tuanya maupun pendidiknya sejak bayi, anak-anak, hingga dewasa. Di antara metode pendidikan terhadap anak perempuan yang dapat dipetik dari kisah masa pengasuhan Maryam ini adalah: 1) Menerapkan metode dialog interaktif sebagai bentuk bimbingan, kasih sayang, dan tanggung jawab terhadap anak yang terutama dilakukan oleh sang ayah, namun hal yang sama juga patut dilakukan oleh sang ibu dan setiap pendidik yang mendidik sang anak; 2) Menerapkan metode pengawasan terhadap anak, berupa memperhatikan, mengontrol, menjaga, melindungi, dari segala aspek kehidupan baik fisik maupun psikologis yang terutama dilakukan oleh sang ayah, namun hal yang sama juga patut dilakukan oleh sang ibu; 3) Bagi orang tua maupun pengasuh yang bertanggung jawab atas sang anak untuk memberi nafkah kepadanya, baik sandang, pangan, papan, dan berusaha mencukupkan kebutuhan-kebutuhannya. Memberi nafkah sebagai bentuk tanggung jawab yang dapat membantu proses pendidikannya pada tahap yang lebih tinggi; 4) Memperbanyak memberi makan anak dengan buah-buahan untuk membantu pertumbuhan dan perkembangan sel-sel baik dalam tubuhnya sehingga berpengaruh pada setiap tahap kehidupan maupun proses pendidikannya.

\section{Referensi}

Al-'Ara>li, A. M. (2017). Huzmah At-Taa>t Allat>i Basatjat fi Al-Qur'a>n AlKari>m. Dipetik September 25, 2018, dari https://vb.tafsir.net

Al-Fad \}1, A. A. (2006). Majma' Al-Baya $>n$ fi Tafsi $>r$ Al-Qu'ra>n. Beirut: $\mathrm{Da}>\mathrm{r}$ al- Murtad\}a.

Al-Hasyimi, A. (2012). Jawa>hir alBala>gah. Kairo: Da>r alTaufi >qiyyah li al-Turasl.

Allen, S \& Daly, K. (2007). The Effect of Father Involvement: An Updated Research Summary of the Evidence. Canada: University of Guelph.

Al-Sya'rawi, M. M. (1991). Tafsir AlSya'rawi-Khawatir Al-Sya'rawi Haula Al-Qur'a>n Al-Kari>m. Akhbar al-Yaum Ida>rah alKutub wa al-Maktabah.

Fiske, J. (2006). Cultural and Communication Studies: Sebuah Pengantar Paling Komprehensif. Yogyakarta: Jalasutra.

Hasan, C. (1994). Dimensi-Dimensi Psikologi Pendidikan. Surabaya: AlIkhlas.

Imran, A. (2011). Semiotika Al-Qur'an: Metode dan Aplikasi Terhadap Kisah Yusuf. Yogyakarta: Teras.

Isma'>il. (1999). Tafsi $>r$ Al-Qur'>an Al'Az\}im. Riyadh: Da>r Thoyyibah.

Mianoki, A. (2012). Ganjaran Memelihara dan Mendidik Anak Perempuan. Dipetik November 24, 2017, dari https://muslim.or.id/10677ganjaran-memelihara-dan$\underline{\text { mendidik-anak-perempuan.html }}$ 
Muhammad. (1993). Tafsi $>r$ Al-Bahr Al$M u h i>t\}$. Beirut: Da>r al-Kutub al-'Ilmiyyah.

Munawwir, A. W. (2001). Al-Munawwir, Kamus Arab-Indonesia. Surabaya: Pustaka Progesif.

Nurhayati, E. (2011). Psikologi Pendidikan Inovatif. Yogyakarta: Pustaka Pelajar.

Perempuan, K. (2018). Catatan Tahunan Kekerasan Terhadap Perempuan 2018. Dipetik September 26, 2018 , dari Komisi Nasional Anti Kekerasan Terhadap Perempuan: https://www.komnasperempuan.go.i d

Priherdityo, E. (2016). Anak-anak yang Makan Buah dan Sayur Lebih Pintar. Dipetik November 27, 2017, dari

https://www.cnnindonesia.com/gay a-hidup/20160915042714-255158370/anak-anak-yang-makanbuah-dan-sayur-lebih-pintar/

S $\} a>f i, M . ~(1995) . ~ I ' r a b ~ A l-Q u r^{\prime} a>n$ wa Sarfuhu> wa Baya>nuhu>. Beirut: Da>r alRasyi $>$ d.

Santrock, J. W. (2008). Psikologi Pendidikan. Jakarta: Kencana.

Schultz, D. P., \& Schultz, S. E. (2013). Sejarah Psikologi Modern. Bandung: Nusa Media.

Tafsir, A. (2014). Ilmu Pendidikan dalam Perspektif Islam. Bandung: Remaja Rosdakarya.

Wade, C \& Tavris, C. (2007). Psikologi (9 ed., Vol. 1). Jakarta: Erlangga.

Wicaksono, A. (2014). Pengkajian Prosa Fiksi. Yogyakarta: Garudhawaca. 